\title{
Tumour necrosis factor signalling in health and disease
}

\section{[version 1; peer review: 2 approved]}

\author{
Jonathan Holbrook1-3, Samuel Lara-Reyna1-3, Heledd Jarosz-Griffiths (iD)1-3, \\ Michael F. McDermott(D) 1,3
}

${ }^{1}$ Leeds Institute of Rheumatic and Musculoskeletal Medicine (LIRMM), Leeds, UK

2Leeds Institute of Medical Research at St. James's, Leeds, UK

${ }^{3}$ Leeds Cystic Fibrosis Trust Strategic Research Centre, Leeds, UK

V1 First published: 28 Jan 2019, 8(F1000 Faculty Rev):111

https://doi.org/10.12688/f1000research.17023.1

Latest published: 28 Jan 2019, 8(F1000 Faculty Rev):111

https://doi.org/10.12688/f1000research.17023.1

\section{Abstract}

The master pro-inflammatory cytokine, tumour necrosis factor (TNF), has been shown to modulate multiple signalling pathways, with wideranging downstream effects. TNF plays a vital role in the typical immune response through the regulation of a number of pathways encompassing an immediate inflammatory reaction with significant innate immune involvement as well as cellular activation with subsequent proliferation and programmed cell death or necrosis. As might be expected with such a broad spectrum of cellular effects and complex signalling pathways, TNF has also been implicated in a number of disease states, such as rheumatoid arthritis, ankylosing spondylitis, and Crohn's disease. Since the time of its discovery over 40 years ago, TNF ligand and its receptors, TNF receptor (TNFR) 1 and 2 , have been categorised into two complementary superfamilies, namely TNF (TNFSF) and TNFR (TNFRSF), and 19 ligands and 29 receptors have been identified to date. There have been significant advances in our understanding of TNF signalling pathways in the last decade, and this short review aims to elucidate some of the most recent advances involving TNF signalling in health and disease.

Keywords

TNF, TNFR, Cell death, Immunometabolism, Autoinflammatory
Open Peer Review

Approval Status

1

2

version 1

28 Jan 2019

Faculty Reviews are review articles written by the prestigious Members of Faculty Opinions. The articles are commissioned and peer reviewed before publication to ensure that the final, published version is comprehensive and accessible. The reviewers who approved the final version are listed with their names and affiliations.

1. Rudi Beyaert, Ghent University,

Technologiepark 927, Belgium

2. Lisa Sedger, The University of Technology ,

Sydney, Australia

Any comments on the article can be found at the end of the article. 
Corresponding authors: Heledd Jarosz-Griffiths (H.H.Griffiths@leeds.ac.uk), Michael F. McDermott (M.McDermott@leeds.ac.uk)

Author roles: Holbrook J: Conceptualization, Project Administration, Visualization, Writing - Original Draft Preparation, Writing - Review \& Editing; Lara-Reyna S: Conceptualization, Writing - Original Draft Preparation, Writing - Review \& Editing; Jarosz-Griffiths H: Conceptualization, Project Administration, Supervision, Writing - Original Draft Preparation, Writing - Review \& Editing; McDermott MF: Conceptualization, Project Administration, Supervision, Writing - Review \& Editing

Competing interests: No competing interests were disclosed.

Grant information: The authors are supported by a grant (SRC009) from the Cystic Fibrosis Trust. JH is partially supported by the Leeds Institute of Medical Research. SL-R is supported by CONACyT.

The funders had no role in study design, data collection and analysis, decision to publish, or preparation of the manuscript.

Copyright: $\odot 2019$ Holbrook J et al. This is an open access article distributed under the terms of the Creative Commons Attribution License, which permits unrestricted use, distribution, and reproduction in any medium, provided the original work is properly cited.

How to cite this article: Holbrook J, Lara-Reyna S, Jarosz-Griffiths $\mathrm{H}$ and McDermott MF. Tumour necrosis factor signalling in health and disease [version 1; peer review: 2 approved] F1000Research 2019, 8(F1000 Faculty Rev):111

https://doi.org/10.12688/f1000research.17023.1

First published: 28 Jan 2019, 8(F1000 Faculty Rev):111 https://doi.org/10.12688/f1000research.17023.1 


\section{Introduction}

Since the identification of tumour necrosis factor (TNF) in $1975^{1}$ and its isolation and characterisation in $1984^{2}$, the 17 $\mathrm{kDa}$ secreted form of this molecule has been established as a potent inflammatory cytokine with a myriad of diverse functions across a number of different cell types. Initially discovered as a serum factor which induced cell death in tumour cells ${ }^{1}$ and thought at that time to be a promising target as a cancer treatment, TNF was later realised to be a potential target for the treatment of inflammatory diseases, such as rheumatoid arthritis (RA) ${ }^{3}$, Crohn's disease $(\mathrm{CD})^{4}$, ankylosing spondylitis (AS) ${ }^{5}$, and psoriasis $^{6}$. However, localised administration of TNF is used as an effective therapy via isolated limb perfusion in patients with melanoma with multiple in-transit metastases ${ }^{7}$.

TNF is produced primarily by monocytes/macrophages, but a number of other cell types, such as $\mathrm{T}$ and $\mathrm{B}$ lymphocytes, mast cells, natural killer cells, neutrophils, fibroblasts, and osteoclasts, can also secrete $\mathrm{TNF}^{8}$, albeit in smaller quantities.

TNF is first produced as a $26 \mathrm{kDa} 233$-amino-acid transmembrane protein (mTNF) that is expressed on the cell surface, where it either continues to reside or is actively cleaved by TNFconverting enzyme to produce a $17 \mathrm{kDa} 157$-amino-acid soluble TNF(sTNF) form; sTNF is subsequently released and becomes detectable in the blood plasma'. mTNF and sTNF both perform cellular functions mediated by either of its two receptors: TNFR1, expressed across all human tissues, and TNFR2, expressed primarily in immune cells, neurons, and endothelial cells ${ }^{10,11}$. mTNF functions as a ligand transmitting cell-to-cell interactions and, when bound to TNFR2 (its primary biological target) ${ }^{12}$, is able to induce a more potent response than STNF; interestingly, mTNF has also been shown to function as a receptor by initiating a cell signalling cascade through outside-to-inside signalling ${ }^{13}$. TNFR1 and 2, though similar in their extracellular structures at the mTNFand sTNF-binding sites, have distinct intracellular structures which bind to a number of adaptor proteins ${ }^{14}$. TNFR1's cytoplasmic tail contains a death domain (DD), thereby allowing it to recruit the TNFR1-associated DD (TRADD) ${ }^{15}$; TNFR2, on the other hand, does not have an intracellular DD and recruits the TNFRassociated factor (TRAF) 1 and 2 proteins instead (Figure 1) $)^{16}$. Whereas both TNFR1 and 2 signalling pathways may lead to the activation of nuclear factor-kappa $\mathrm{B}(\mathrm{NF}-\kappa \mathrm{B})$ and the induction of a cell survival response, TNFR1 is also capable of inducing a cell death response depending on prevailing physiological circumstances; however, the regulation of the two TNFRs is dependent on the cellular environment and is not fully understood (Figure 1$)^{17}$. The past decade has seen remarkable progress in the elucidation of regulatory cross-talk between TNFR1 and 2 as well as the individual but complementary functions of these two pleiotropic receptors ${ }^{18,19}$.

Upon binding of TNF to TNFR1, TNFR1 undergoes a conformational change in its DD, whereby both TRADD and receptorinteracting serine/threonine protein kinase 1 (RIPK1) are recruited, leading to the formation of complex I and the initiation of cell survival via activation of the NF- $\mathrm{BB}$ pathway (Figure 2) ) $^{20-22}$. TNF-mediated cell death is highly dependent on various cell death check points, which regulate the pro-survival pathway; when these check points are disrupted, TNF-mediated signalling occurs through the formation of complexes IIa, IIb, and $\mathrm{IIc}^{23}$. The ubiquitination status of RIPK1 is a critical determinant of whether a particular signalling pathway promotes cell survival, through complex $\mathrm{I}^{24}$, apoptosis (controlled cell death), via complex $\mathrm{IIb}^{25,26}$, or necrosis (uncontrolled cell death), through complex IIc ${ }^{27,28}$.

TNF signalling is tightly regulated by post-translational ubiquitination, an essential mechanism for the regulation of many biological processes. Ubiquitin ( $\mathrm{Ub}$ ) chains are assembled in response to activation of the TNF receptors and then attached to target substrates to modulate protein function. The type of $\mathrm{Ub}$ chains is determined by their specific linkage type, which are assembled to generate distinct intracellular signals. Deubiquitinase (DUB) enzymes reverse the process of ubiquitination by hydrolysing $\mathrm{Ub}$ moieties from the modified protein substrates ${ }^{29}$. Ub retains seven lysine sites (K6, K11, K27, K29, K33, K48, and K63) at the $\mathrm{N}$-terminal methionine (Met-1) and the $\mathrm{C}$-terminal glycine site. The main sites of interest are $\mathrm{K} 48$ and $\mathrm{K} 63$, as they are essential for the activation of the NF- $\mathrm{KB}$ pathway ${ }^{30}$.

The activation of complex I relies on the ubiquitination of RIPK1 and consists of TRADD ${ }^{15}$, RIPK1 ${ }^{21}$, TRAF2 or $5^{31}$, cellular inhibitor of apoptosis protein (cIAP) 1 or $2^{32}$, and linear $\mathrm{Ub}$ chain assembly complex (LUBAC) (Figure 2$)^{33}$. LUBAC is composed of three proteins: heme-oxidised iron regulatory protein (IRP) 2 Ub ligase 1 (HOIL-1), shank-associated RH domain-interacting protein (SHARPIN), and HOIL-1 interacting protein (HOIP). cIAP and LUBAC add K63-linked and Met1-linked polyUb chains, respectively, to RIPK1, stabilising the Ub structure and amplifying its signal ${ }^{33-35}$. This leads to the recruitment of transforming growth factor-beta (TGF- $\beta$ )-activated kinase (TAK) 1 complex, consisting of TAK-binding protein (TAB) 2 and 3, and inhibitor of $\kappa \mathrm{B}(\mathrm{I} \kappa \mathrm{B})$ kinase (IKK) complex, composed of the $\mathrm{NF}-\kappa \mathrm{B}$ essential modulator (IKK $\gamma$, also known as NEMO), IKK $\alpha$, and IKK $\beta^{24}$. The TAK1 complex phosphorylates mitogen-activated protein kinase (MAPK), leading to a signalling cascade whereby c-Jun N-terminal kinase (JNK), p38, and AP1 transcription factors are activated, and the IKK $\beta$ activates NF- $\mathrm{BB}$. This ultimately leads to pro-survival signalling, where inflammation and the proliferation of immune cells are induced ${ }^{24}$. Following the activation of NF- $\kappa \mathrm{B}$, cellular FLICE-like inhibitory protein long $\left(\mathrm{cFLIP}_{\mathrm{L}}\right)$ translocates to complex IIa in order to prevent caspase-8 activation. However, if the late NF- $\mathrm{BB}$-dependent check point is disrupted and $\mathrm{CFLIP}_{\mathrm{L}}$ levels are consequently reduced, apoptosis is initiated via complex IIa (composed of TRADD, FASassociated DD [FADD], and pro-caspase-8) through autoactivation of pro-caspase- $8^{36-38}$. In contrast to the late check point, the early check point, which occurs immediately after ligand binding, is initiated by the ubiquitination of RIPK 1 by cIAP and LUBAC (Figure 2) ) $^{39-41}$.

When RIPK1 is not ubiquitinated, complex IIb is formed; in order for this to occur, the cylindromatosis tumour suppressor protein DUB (CYLD) enzyme deubiquitinates RIPK1, thereby allowing it to disassociate from complex $\mathrm{I}^{42}$ and form complex 


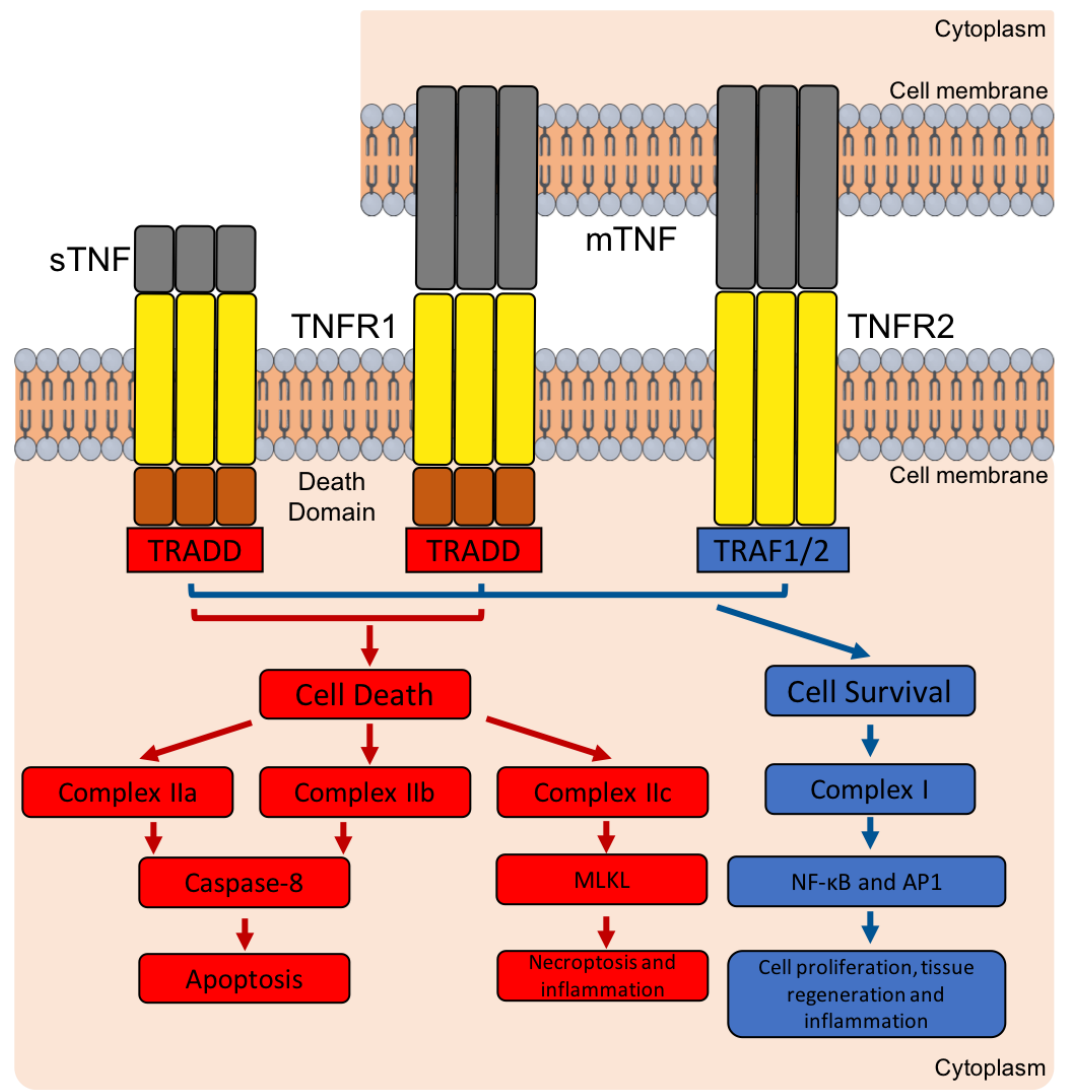

Figure 1. Overview of tumour necrosis factor (TNF): TNF receptor $\mathbf{1 / 2}$ (TNFR1/2) signalling pathways. Both soluble TNF (sTNF) and membrane TNF (mTNF) activate TNFR1. TNFR1 contains a death domain which interacts with TNFR1-associated death domain (TRADD). Depending on the ubiquitination state of receptor-interacting serine/threonine-protein kinase 1 (RIPK1), the cell undergoes apoptosis (via complexes IIa and IIb), necrosis (via complex IIc), or cell survival (via complex I). The formation of complexes Ila and IIb leads to the cleavage of pro-caspase-8 to form caspase-8 and induction of apoptosis. When complex Ilc forms, the mixed lineage kinase domain-like protein (MLKL) is activated, inducing necroptosis. Upon the formation of complex I, cell survival is induced via the activation of nuclear factor-kappa $\mathrm{B}(\mathrm{NF}-\mathrm{kB})$ and AP1 transcription factors because of RIPK1 ubiquitination. TNFR2, however, is activated primarily by mTNF and does not contain an intracellular death domain but interacts directly with TNFR-associated factor (TRAF) 1 and 2 to induce the formation of complex I with induction of homeostatic signals.

IIb, whereby TRADD is replaced by RIPK3, upon degradation of cIAP1 and $2^{25,26,43}$. This, in turn, leads to the cleavage of pro-caspase- 8 to caspase- 8 , and activation of the caspase signalling cascade results in apoptosis (Figure 2). To ensure that apoptosis, and not necrosis (unregulated cell death), is induced, which could lead to unwanted inflammation and damage to the surrounding tissues, caspase- 8 or pro-caspase- 8 in complex with $\mathrm{cFLIP}_{\mathrm{L}}$ is required to cleave RIPK1 and $3^{25,44}$. However, RIPK1 and 3 may, on occasions, remain uncleaved, leading to their aggregation and the formation of complex IIc, with the resultant activation of mixed lineage kinase domain-like protein (MLKL) and the induction of a regulated form of necrotic cell death, necroptosis (Figure 2) 27,28 $^{2}$

TNFR2 interacts directly with TRAF1 or 2 to recruit cIAP1 or 2 to promote cell survival signalling through the formation of complex I and the induction of NF- $\mathrm{KB}$, MAPK, and Akt, promoting cell proliferation and tissue regeneration. The binding of TRAF2 to TNFR2 is considerably weaker than TRAF2's binding to
TRADD ${ }^{45,46}$, indicating a regulatory role of the TNFR1 signalling pathway ${ }^{45,47}$. It is hoped that, through greater understanding of TNF signalling in health and disease, improved therapies can be developed to inhibit this potent cytokine in a more target-specific manner.

Throughout the TNF signalling pathway, there are a number of proteins that are essential for negative regulation of the pathway. A20 contains both DUB and E3 ligase domains and plays a vital regulatory role at multiple steps of the TNF signalling pathway, such as its removal of K48- and K63-linked Ub chains from RIP1 through its zinc finger (ZF) 4 domain ${ }^{48,49}$ and its inhibition of the interaction between LUBAC and IKK $\gamma$ through binding to their linear Ub chains via A20's ZF7 domain upon TNF stimulation $^{50,51}$. A20, as well as the regulatory molecule TAX1BP1, has also been shown to inhibit the E3 ligase activities of TRAF2, TRAF6, and cIAP1 by interfering with E2 Ub enzymes Ubc13 and UbcH5c, disrupting NF- $\kappa \mathrm{B}$ signalling ${ }^{52}$. In 2015, it was documented, in a mouse embryonic fibroblast (MEF) 


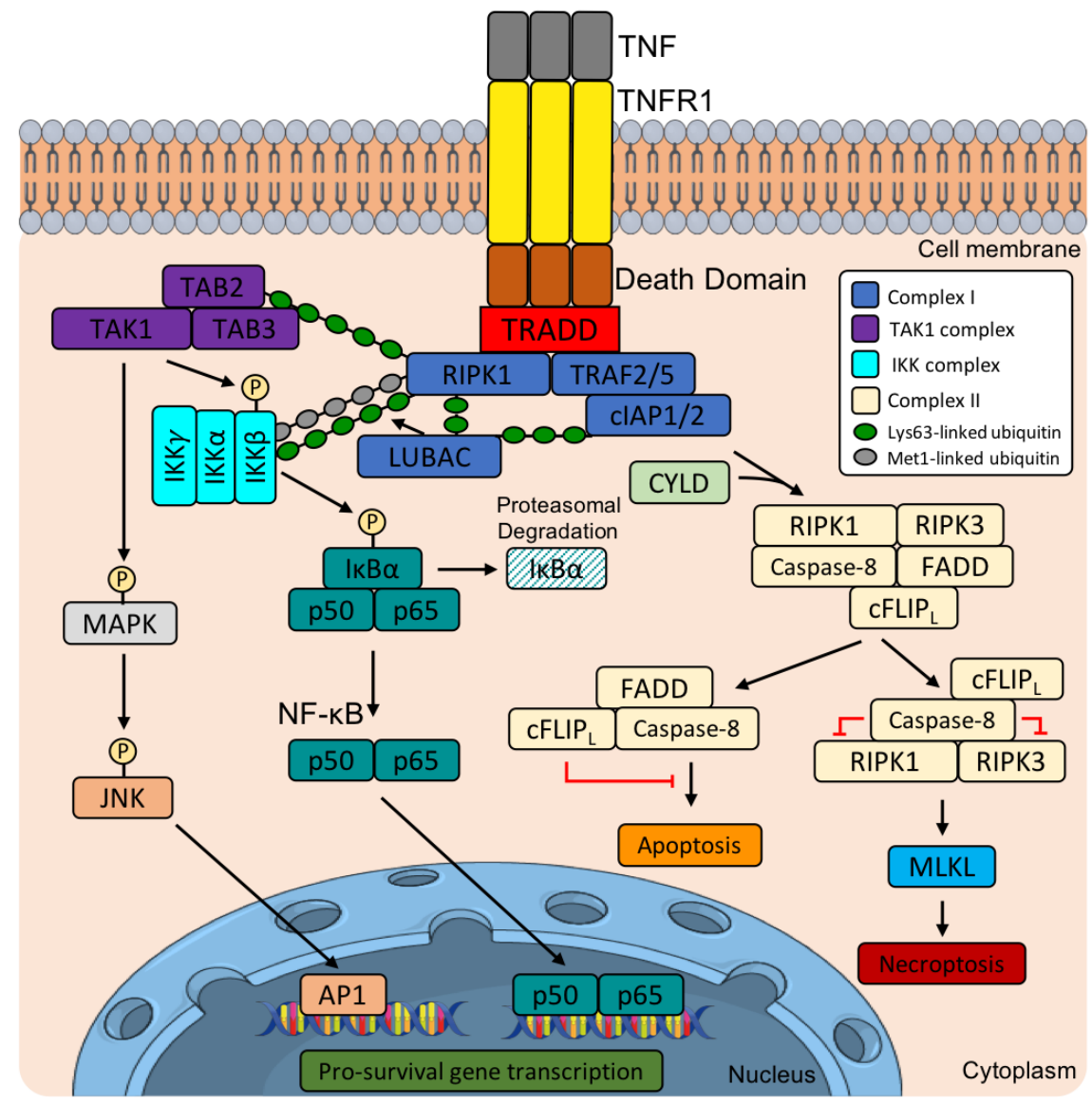

Figure 2. Overview of the tumour necrosis factor receptor 1 (TNFR1) signalling pathway. In the binding of TNF to TNFR1, TNFR1 recruits the TNFR1-associated death domain (TRADD), which then binds to receptor-interacting serine/threonine-protein kinase 1 (RIPK1), TNFR-associated factor 2 or 5 (TRAF2/5), and cellular inhibitor of apoptosis protein 1 or 2 (clAP1/2) to form complex I. clAP1/2 and the linear ubiquitin chain assembly complex (LUBAC), consisting of HOIP, HOIL, and SHARPIN, add Met1-linked and Lys63-linked polyubiquitin chains, respectively, to RIPK1. This stabilises RIPK1, amplifying its signal. Lys63-linked chains on RIPK1 recruit the transforming growth factor-beta (TGF $\beta$ )-activated kinase 1 (TAK1) complex, consisting of TGF $\beta$-activated kinase 1 and mitogen-activated protein kinase (MAPK)binding protein 2 and 3 (TAB2 and 3) and TAK1. The TAK1 complex phosphorylates MAPK, Jun N-terminal kinase (JNK), and the IKB kinase (IKK) complex. This results in the translocation of transcription factors AP1 and nuclear factor-kappa B (NF-kB) into the nucleus, leading to the transcription of target genes. RIPK1 is deubiquitinated by cylindromatosis tumour suppressor protein deubiquitinase (CYLD), facilitating its dissociation from complex I to form complex IIb, consisting of RIPK1, RIPK3, FAS-associated death domain (FADD), caspase-8, and FLICElike inhibitory protein long $\left(c F L I P_{L}\right)$. cFLIP regulates both the apoptosis and the necrosis pathway, preventing caspase-8 activation to avert apoptosis. CFLIP, acts in complex with caspase-8 to cleave RIPK1 and RIPK3 to inhibit their aggregation and the activation of mixed lineage kinase domain-like protein (MLKL), which would result in necrosis. HOIL-1, heme-oxidised iron regulatory protein 2 ubiquitin ligase 1; HOIP, HOIL-1 interacting protein.

model, that binding of A20 to linear Met1-linked polyUb chains protected the MEFs from CYLD-mediated degradation. This was shown to be dependent on A20's ZF7 domain but was independent of its DUB activity and protected cells from TNF-induced RIPK1-dependent apoptosis (RDA) ${ }^{53}$. Another DUB, ovarian tumour (OTU) DUB with linear linkage specificity (OTULIN), acts via its specific cleavage of Met1-linked polyUb chains after it binds to the HOIP component of the LUBAC ${ }^{54}$. CYLD is another negative regulator of the TNF signalling pathway, removing $\mathrm{Ub}$ chains from several proteins such as TRAF2, TRAF6, IKK $\gamma$, and RIPK1 to regulate the NF- $\kappa \mathrm{B}$ and JNK pathways ${ }^{55}$.

\section{Cell death}

The ubiquitination status of RIPK1 is a critical determinant of whether a cell undergoes RDA; a recent study describes a "detergent insoluble, highly ubiquitinated and activated RIPK1 pool" ${ }^{56}$, termed iuRIPK1, which acts as an intermediate between complex I and cytosolic complex IIb formation and caspase activation. Using a systematic screen for RDA, the investigators found that iuRIPK1 is regulated by Parkinson's disease-associated leucine-rich repeat kinase 2 (LRRK2), E3 Ub ligase, c-Cbl, and ALS-associated NEK1, suggesting a mechanistic link between RDA and neurodegenerative conditions ${ }^{56}$. It is well documented that, in addition to its Ub status, kinase activity of RIPK1 is 
essential for RDA and necroptosis, both being induced by $\mathrm{TNF}^{57-59}$. In 2018, Meng et al. reported that C-terminal DD dimerisation of RIPK1, via K584, serves as an amplification mechanism to promote RIPK1 kinase activity and that increased expression, under pathological conditions, may promote its dimerisation and activation $^{60}$. In light of these discoveries, the question arises as to whether detergent-insoluble lipid rafts are providing a platform for the assembly of cell surface signalling complexes, under certain pathological conditions, and thus might act as a critical determinant in driving RIPK1-mediated cell death ${ }^{61}$. Recent research has also found that RIPK1 prevents skin inflammation, via the inhibition of RIPK3-MLKL-dependent necroptosis, mediated by the cytoplasmic DNA sensor protein, Z-DNA-binding protein $(\mathrm{ZBP} 1)^{62,63}$, and that deficiency of RIPK3, as well as an inactive form of RIPK3, reduces necroptosis and thereby the severity of inflammation in mouse models of tissue injury ${ }^{64}$.

Controversy hangs over the role of A20 DUB, which has been shown in separate studies to either protect or promote TNF-mediated RDA $^{53,65}$. A recently published report by Garcia-Carbonell et $a{ }^{65}{ }^{6}$ reported increased levels of $A 20$ gene expression in patients with irritable bowel disease (IBD), and intestinal epithelial cells have increased susceptibility to TNF-induced cell death. Similarly, stabilising the function of $A 20$, in the form of homodimers, facilitated ripoptosome complex (consisting of RIP1 and cIAP1 and 2) assembly by binding linear Ub chains via ZF7, protecting RIPK1 from deubiquitination, resulting in enhanced caspase- 8 recruitment and activation ${ }^{65}$. A20 has also been shown to protect cells from necroptosis through the deubiquitination of RIPK3 in both T cells and fibroblasts ${ }^{66}$.

Alongside their functional roles as E3 Ub ligases, the cIAPs are critical regulators of pro-inflammatory signalling pathways ${ }^{67}$. The loss of IAP induces not only the formation of complex IIb and stimulates RDA but also caspase-8-dependent interleukin-1 beta (IL-1 $\beta$ ) maturation and NLRP3 inflammasome signalling in macrophages, in a TLR4/TRIF-dependent manner which is independent of TNFR $1^{68,69}$. Blocking caspase- 8 activity, followed by interferon gamma (IFN $\gamma$ ) priming, rendered neutrophils sensitive to TNFR1-dependent necroptosis via the RIPK3-MLKL pathway, leading to NLRP3 activation ${ }^{70}$. The finding that cell death pathways are distinctly regulated in neutrophils, as compared with other myeloid cells, signifies the importance of cell type on immune signalling pathways in orchestrating a coordinated inflammatory response.

\section{Cellular activation and proliferation}

TNF is known to have widespread and profound effects on both the activation and the proliferation of different subsets of immune cells in several disease states. In vitro anti-TNF blockage, used in T-cell monocyte co-cultures of patients with the autoimmune disorder thrombocytopenia, produced a robust proliferation of the immunomodulatory regulatory $\mathrm{T}$ (Treg) cells ${ }^{71}$; interestingly, this Treg cell expansion was dependent on TNFR2 and not TNFR1. Blockage of TNFR2 resulted in a robust expansion of Treg cells, whereas neutralisation of TNFR1 had no effect on this Treg cell expansion ${ }^{71}$. Therefore, TNFR2 might be considered a potential novel therapeutic target for immunomodulation, not only in thrombocytopenia but also in other unrelated immune disorders associated with decreased levels of Treg cells, such as RA, AS, systemic lupus erythematosus (SLE), IBD, and psoriasis $^{72}$. For a recent review of anti-TNFR2 therapy, see Zou et al. ${ }^{73}$.

Another report showed that inhibition of TNF signalling, by a number of anti-TNF biological treatments, primed naïve $\mathrm{CD} 4^{+}$ $\mathrm{T}$ cells towards a regulatory phenotype with high expression of IL-10 and reduced IFN $\gamma$ production ${ }^{74}$. Patients with cardiovascular disease often exhibit high levels of blood TNF, which are positively correlated with the formation of foam cells, and there are further repercussions for the development of plaques and blood clots ${ }^{75}$. These observations were supported by both in vitro and in vivo experiments that confirmed that high levels of TNF enhanced the expression of adhesion molecules and scavenger receptors on blood monocytes ${ }^{75}$. TNF has an important role, not only in immune cells but also in the regulation of circadian rhythms by the central nervous system. One study reported that TNF stimulation of the suprachiasmatic nucleus exerted an important influence on the regulation of circadian rhythms, through the activation of TNFR1 after lipopolysaccharide (LPS) inoculation, mainly during the early period of the night, when TNFR1 showed its highest expression ${ }^{76}$. This regulation has novel implications for several disorders and might explain some of the observed disruption of circadian rhythms during disease $\mathrm{e}^{76-78}$, perhaps due to higher expression of TNF in activated immune cells.

A20 has been shown to promote cell survival of CD4 T cells by initiation of autophagy via its inhibition of mammalian target of rapamycin (mTOR) $)^{79}$ as well as to restrain the development of Treg cells, as A20-deficient mice present with enlarged thymic and peripheral Treg cell compartments ${ }^{80}$. A20 has also been shown to exert an important defence role against bacterial infections, as it enhances secondary $\mathrm{CD}^{+} \mathrm{T}$-cell responses but reduces the primary response ${ }^{81}$. SHARPIN, a component of LUBAC, has a number of modulating effects on $\mathrm{T}$ cells; for example, defective SHARPIN results in a significant reduction in the overall population of Treg cells and their ability to function correctly $^{82}$. Furthermore, deficiency of SHARPIN leads to reduced numbers of $\mathrm{CD}^{+} \mathrm{CD}^{2} 5^{+} \mathrm{FOXP} 3^{+}$Treg cells in the blood, spleen, lymph nodes, and thymus ${ }^{83}$. HOIL-1, which is another component of LUBAC, has been reported to be cleaved by mucosaassociated lymphoid tissue lymphoma translocation 1 (MALT1), leading to its becoming a potent inhibitor of LUBAC-induced $\mathrm{NF}-\kappa \mathrm{B}$ signalling in activated $\mathrm{T}$ cells ${ }^{84-87}$; other NF- $\mathrm{\kappa B}$ regulatory proteins that are cleaved by MALT1 include A20 ${ }^{88}, \mathrm{RelB}^{89}$, and CYLD $^{90}$, not to mention the auto-proteolytic cleavage of MALT1 $^{91}$.

A recent study focusing on innate immune cells showed the importance of TNF activation of these cells in cerebral tuberculosis, although neuron-derived TNF also plays a limited role ${ }^{92}$. TNF has a ubiquitous influence on different cells and tissues and has an important role in the tumour microenvironment. A recent publication reported that regulation of the immunomodulatory check point programmed death-ligand 1 (PD-L1) in tumourassociated macrophages and monocytes was strongly increased 
by TNF in a B16 melanoma mouse model of disease ${ }^{93}$. By using TNFR $^{-/-}$mice (strain B6.129 S-Tnfrsf1 $\mathrm{a}^{\mathrm{tm} 1 \mathrm{Imx}} \mathrm{Tnfrsfl}^{\mathrm{tm} \operatorname{lImx} / J}$ ), the researchers found a significant decrease in numbers of tumourassociated macrophages and dendritic cells expressing PD-L1 and an associated reduction in the size of the tumours ${ }^{93}$. In a separate study, TNF was reported to activate the NF- $\kappa B$ signalling pathway and upregulate PD-L1 in human prostate and colon cancer cells, thereby promoting immunosuppression and favouring the tumour microenvironment ${ }^{94}$. Immunotherapy has proven to be an effective option in the treatment of several cancers with high expression of PD-L1; thus, incorporating anti-TNF biologics into this therapeutic regimen may result in improved outcomes for certain types of cancers.

\section{Immunometabolism}

The link between metabolism and immunity first became apparent in the 1980s, when macrophage-conditioned media, stimulated with LPS, was found to increase lipoprotein lipase expression and promote resistance to insulin in adipocytes ${ }^{95,96}$. It was later observed that obese rats expressed increased levels of TNF in their adipose tissue and that obese humans also expressed TNF at higher levels in their muscle tissue ${ }^{97-99}$. In obese rats, TNF inhibition led to improved metabolism of glucose and improved insulin sensitivity ${ }^{100,101}$; however, when TNF was administered, the opposite effects occurred ${ }^{102,103}$.

The essential glycolytic enzyme, glyceraldehyde 3-phosphate dehydrogenase (GAPDH), under low glycolysis conditions has been linked to regulation of the inflammatory response, as it binds to TNF mRNA in monocytes and macrophages and posttranscriptionally inhibits its production ${ }^{104,105}$, thus showing that the metabolic state of immune cells helps regulate various immune responses. Additionally, the product of GAPDH, nicotinamide adenine dinucleotide (NADH), significantly inhibited TNF secretion in macrophages ${ }^{105}$.

The anti-inflammatory metabolite itaconate was found to inhibit TNF in an LPS-stimulated mouse model as well as in human peripheral blood mononuclear cells; however, no effects were observed in human macrophages ${ }^{106}$. Immature monocyte-derived dendritic cells have a high expression of the extracellular succinate sensor, a G-protein-coupled receptor known as GPR91, and these cells were shown to have enhanced production of TNF due to succinate when stimulated with the TLR7 ligand imiquimod or the TLR3 ligand polyinosinic-polycytidylic acid (poly[I: C] $)^{106}$. Macrophages have also been recognised to upregulate their expression of GPR91 and release succinate into the extracellular milieu under inflammatory signals, which may lead to exacerbations of RA, as rheumatoid joints have high levels of succinate present ${ }^{107}$.

Cis-aconitate decarboxylase (CAD), the enzyme product of immune-responsive gene 1 (IRG1), catalyses the decarboxylation of cis-aconitate to produce itaconate, and this reaction is induced by heme oxygenase 1 (HO-1) activity. Carbon monoxide induction of HO-1 led to reduced TNF levels via upregulated IRG1 expression, demonstrating IRG1's anti-inflammatory effects $^{108}$. Another glycolytic enzyme, alpha-enolase (ENO1), has been shown to have inflammatory effects when expressed on the surface of monocytes and macrophages by contributing to the production of inflammatory cytokines, such as TNF, in the synovium of patients with RA and also in the type II collagen model of arthritis ${ }^{109}$. ENO1 also plays a role in both the induction and the function of Treg cells via the promotion of Foxp3 splicing ${ }^{110}$.

A recent study showed that inhibition of complex II of the mitochondria reduces the production of TNF in macrophages ${ }^{111}$, and another study demonstrated the importance of mitochondrial citrate carrier (CIC) in TNF-triggered inflammation, whereby the CIC is transcriptionally upregulated under TNF stimulation via $\mathrm{NF}-\kappa \mathrm{B}$ and plays an essential role in regulating the downstream production of nitric oxide and prostaglandins ${ }^{112}$. In macrophages, citrate accumulation is essential for fatty acid synthesis, in a murine model of type 2 diabetes, which enhances inflammatory signalling through TNF production ${ }^{113,114}$.

\section{Tumour necrosis factor signalling-related inflammatory disease}

Although TNF plays an essential role in health, it also exerts a double-edged sword effect in several disease states. Indeed, in 1999, mutations in the TNFRSF1A gene, encoding TNFR1, were found to be associated with episodic fevers and profound localised inflammation; consequently, TNFR1-associated periodic syndrome (TRAPS) was defined as one of the disease entities under the collective heading of autoinflammatory disease ${ }^{115}$. The term "autoinflammation" was used to refer to the increasing number of clinical disorders characterised by episodes of seemingly unprovoked inflammation in the absence of high autoantibodies titres or antigen-specific $\mathrm{T}$ lymphocytes. Anti-TNF therapy was used for the treatment of TRAPS with some initial success; however, a large number of these patients eventually become resistant to this treatment ${ }^{116,117}$, and an increasing number of reports subsequently revealed the clinical benefits of anti-IL-1 $\beta$ and/or anti-IL-6 therapy in the forms of canakinumab and tocilizumab, respectively ${ }^{118-123}$. The current standard treatment for the more severe cases of TRAPS is IL- $1 \beta$ blockade.

Recently, the scope of autoinflammation has been broadened to encompass some abnormalities of deubiquitination and redox homeostasis under the name of ubiquitination-associated autoinflammatory diseases (UADs). There are a number UADs, but only two are known to directly affect the TNF signalling pathway, namely otulipenia/OTULIN-related autoinflammatory syndrome (ORAS) and A20 haploinsufficiency (HA20) ${ }^{124}$. The DUB OTULIN is an essential negative regulator of inflammation and prevention of autoimmunity involving the TNF pathway. Genetic alterations of DUBs have been associated with neurodegenerative diseases and cancers ${ }^{125}$; also, two unrelated monogenic systemic inflammatory diseases have been associated with defective DUBs ${ }^{124}$. Otulipenia is caused by loss-of-function mutations in the linear (Met-1) OTULIN with resulting dysregulation of the deubiquitination process ${ }^{126,127}$. Increased signalling in the canonical NF- $\kappa \mathrm{B}$ pathway with overproduction of TNF, IL-1 $\beta$, IL-6, IL-12, IL-18, and IFN $\gamma$ in response to LPS stimulation was reported in these patients. Anti-TNF therapy was found to normalise markers of active inflammation, 
including C-reactive protein (CRP) and erythrocyte sedimentation rate (ESR), and control disease activity in otulipenia ${ }^{124}$.

Loss-of-function mutations in the TNFAIP3 gene, which codes for $\mathrm{A} 20$, result in the UAD disorder, HA20, so named because of loss of function of one of the copies of the $A 20$ gene, leading to early onset systemic inflammation and a disorder resembling Behçet's disease ${ }^{128}$; for a recent review of HA20, see Kadowaki et al. ${ }^{129}$. Polymorphisms in TNFAIP3 have also been linked to RA, SLE, psoriasis, and CD susceptibility through genome-wide association studies ${ }^{128,130-136}$. A20 function has also been associated with a protective role in RA, as it negatively regulates NLRP3 inflammasome activity ${ }^{137}$.

Keratinocyte-specific deletion of the LUBAC components HOIP or HOIL-1 results in a lethal inflammatory skin disease, caused by TNFR1-induced caspase-8-mediated apoptosis, that occurs independently of RIPK1 kinase activity ${ }^{138}$. This differential effect in cell death pathway aetiology provides clues to the benefits of various treatment pathways. Interestingly, patients with LUBAC-inactivating germline mutations, such as HOIL-1 and HOIP mutations, also have primary immunodeficiency and autoinflammation $^{139-141}$. Expression of TNFR1 in peripheral blood mononuclear cells from patients with RA has been positively correlated with the efficacy of therapies received ${ }^{142}$; furthermore, the expression of both TNFR1 and 2 is downregulated in B cells of patients with RA compared with healthy controls ${ }^{142}$.

\section{Summary}

The identification of TNF and the development of anti-TNF therapies for associated disorders were revolutionary moments in disease research, resulting in vast improvement in the quality of life for patients with these debilitating diseases. With the everexpanding understanding of TNF and its signalling pathways, it is hoped that the new research focus on combination therapies, and not just anti-TNF, will further improve these patients' quality of life.

\section{Grant information}

The authors are supported by a grant (SRC009) from the Cystic Fibrosis Trust. JH is partially supported by the Leeds Institute of Medical Research. SL-R is supported by CONACyT.

The funders had no role in study design, data collection and analysis, decision to publish, or preparation of the manuscript.

\section{Acknowledgments}

The authors would like to thank Chi Wong for his input into the completion of this review.
1. Carswell EA, Old LJ, Kassel RL, et al: An endotoxin-induced serum factor that causes necrosis of tumors. Proc Natl Acad Sci U S A. 1975; 72(9): 3666-70. PubMed Abstract | Publisher Full Text | Free Full Text

2. Aggarwal BB, Moffat B, Harkins RN: Human lymphotoxin. Production by lymphoblastoid cell line, purification, and initial characterization. J Biol Chem. 1984; 259(1): 686-91. PubMed Abstract

3. Seymour HE, Worsley A, Smith JM, et al.: Anti-TNF agents for rheumatoid arthritis. Br J Clin Pharmacol. 2001; 51(3): 201-8. PubMed Abstract | Publisher Full Text | Free Full Text

4. Ghosh S: Anti-TNF therapy in Crohn's disease. Novartis Found Symp. 2004; 263 193-205.

PubMed Abstract

5. Coates LC, Marzo-Ortega H, Bennett AN, et al:: Anti-TNF Therapy in Ankylosing Spondylitis: Insights for the Clinician. Ther Adv Musculoskelet Dis. 2010; 2(1): 37-43.

PubMed Abstract | Publisher Full Text | Free Full Text

6. Kircik LH, Del Rosso JQ: Anti-TNF agents for the treatment of psoriasis. J Drugs Dermatol. 2009; 8(6): 546-59. PubMed Abstract

7. Deroose JP, Eggermont AM, van Geel AN, et al: 20 years experience of TNFbased isolated limb perfusion for in-transit melanoma metastases: TNF dose matters. Ann Surg Oncol. 2012; 19(2): 627-35. PubMed Abstract | Publisher Full Text | Free Full Text

8. F Grivennikov SI, Tumanov AV, Liepinsh DJ, et al.: Distinct and nonredundant in vivo functions of TNF produced by $t$ cells and macrophages/neutrophils: Protective and deleterious effects. Immunity. 2005; 22(1): 93-104. PubMed Abstract | Publisher Full Text | F1000 Recommendation

9. Black RA, Rauch CT, Kozlosky CJ, et al.: A metalloproteinase disintegrin that releases tumour-necrosis factor-alpha from cells. Nature. 1997; 385(6618): 729-33.

PubMed Abstract | Publisher Full Text

10. Faustman D, Davis M: TNF receptor 2 pathway: drug target for autoimmune diseases. Nat Rev Drug Discov. 2010; 9(6): 482-93. PubMed Abstract | Publisher Full Text
11. Carpentier $I$, Coornaert $B$, Beyaert $R$ : Function and regulation of tumor necrosis factor receptor type 2. Curr Med Chem. 2004; 11(16): 2205-12. PubMed Abstract | Publisher Full Text

12. Grell $\mathrm{M}$, Douni $\mathrm{E}$, Wajant $\mathrm{H}$, et al: The transmembrane form of tumor necrosis factor is the prime activating ligand of the $\mathbf{8 0} \mathrm{kDa}$ tumor necrosis factor receptor. Cell. 1995; 83(5): 793-802. PubMed Abstract | Publisher Full Text

13. Eissner G, Kolch W, Scheurich P: Ligands working as receptors: reverse signaling by members of the TNF superfamily enhance the plasticity of the immune system. Cytokine Growth Factor Rev. 2004: 15(5): 353-66. PubMed Abstract | Publisher Full Text

14. Tartaglia LA, Weber RF, Figari IS, et al.: The two different receptors for tumor necrosis factor mediate distinct cellular responses. Proc Natl Acad Sci U S A. 1991; 88(20): 9292-6. PubMed Abstract | Publisher Full Text | Free Full Text

15. Hsu H, Xiong J, Goeddel DV: The TNF receptor 1-associated protein TRADD signals cell death and NF-kappa B activation. Cell. 1995; 81(4): 495-504. PubMed Abstract | Publisher Full Text

16. Rothe M, Sarma V, Dixit V, et al:: TRAF2-mediated activation of NF-kappa B by TNF receptor 2 and CD40. Science. 1995; 269(5229): 1424-7. PubMed Abstract | Publisher Full Text

17. Pimentel-Muiños FX, Seed B: Regulated commitment of TNF receptor signaling: a molecular switch for death or activation. Immunity. 1999; 11(6): 783-93. PubMed Abstract | Publisher Full Text

18. Naudé $P J$ den Boer JA, Luiten PG, et al: Tumor necrosis factor receptor crosstalk. FEBS J. 2011; 278(6): 888-98. PubMed Abstract | Publisher Full Text

19. Sedger LM, McDermott MF: TNF and TNF-receptors: From mediators of cell death and inflammation to therapeutic giants - past, present and future. Cytokine Growth Factor Rev. 2014; 25(4): 453-72. PubMed Abstract | Publisher Full Text

20. Ting AT, Pimentel-Muiños FX, Seed B: RIP mediates tumor necrosis factor receptor 1 activation of NF-kappaB but not Fas/APO-1-initiated apoptosis. EMBO J. 1996; 15(22): 6189-96.

PubMed Abstract | Publisher Full Text | Free Full Text 
21. Hsu H, Huang J, Shu HB, et al.: TNF-dependent recruitment of the protein kinase RIP to the TNF receptor-1 signaling complex. Immunity. 1996; 4(4): 387-96.

PubMed Abstract | Publisher Full Text

22. Wajant $\mathrm{H}$, Scheurich $\mathrm{P}$ : TNFR1-induced activation of the classical NF- $\mathrm{KB}$ pathway. FEBS J. 2011; 278(6): 862-76

PubMed Abstract | Publisher Full Text

23. Ting AT, Bertrand MJM: More to Life than NF-KB in TNFR1 Signaling. Trends Immunol. 2016; 37(8): 535-45.

PubMed Abstract | Publisher Full Text | Free Full Text

24. Brenner D, Blaser $\mathrm{H}$, Mak TW: Regulation of tumour necrosis factor signalling: live or let die. Nat Rev Immunol. 2015; 15(6): 362-74. PubMed Abstract | Publisher Full Text

25. F Micheau O, Tschopp J: Induction of TNF receptor I-mediated apoptosis via two sequential signaling complexes. Cell. 2003; 114(2): 181-90. PubMed Abstract | Publisher Full Text | F1000 Recommendation

26. Wang L, Du F, Wang X: TNF-alpha induces two distinct caspase-8 activation pathways. Cell. 2008; 133(4): 693-703.

PubMed Abstract | Publisher Full Tex

27. Pasparakis $M$, Vandenabeele $P$ : Necroptosis and its role in inflammation Nature. 2015; 517(7534): 311-20.

PubMed Abstract | Publisher Full Text

28. F Sun L, Wang $\mathrm{H}$, Wang $\mathrm{Z}$, et al:: Mixed lineage kinase domain-like protein mediates necrosis signaling downstream of RIP3 kinase. Cell. 2012; 148(1-2) 213-27.

PubMed Abstract | Publisher Full Text | F1000 Recommendation

29. F Swatek KN, Komander D: Ubiquitin modifications. Cell Res. 2016; 26(4): 999-422.

PubMed Abstract | Publisher Full Text | Free Full Text | F1000 Recommendation

30. $\mathrm{F}$ Wu $\mathrm{Y}, \mathrm{Kang} \mathrm{J}$, Zhang $\mathrm{L}$, et al.: Ubiquitination regulation of inflammatory responses through NF-кB pathway. Am J Transl Res. 2018; 10(3): 881-91. PubMed Abstract | Free Full Text | F1000 Recommendation

31. Tada K, Okazaki T, Sakon S, et al.: Critical roles of TRAF2 and TRAF5 in tumor necrosis factor-induced NF-kappa $B$ activation and protection from cell death. J Biol Chem. 2001; 276(39): 36530-4.

PubMed Abstract | Publisher Full Text

32. Varfolomeev E, Goncharov T, Fedorova AV, et al.: c-IAP1 and c-IAP2 are critical mediators of tumor necrosis factor alpha (TNFalpha)-induced NF-kappaB activation. J Biol Chem. 2008; 283(36): 24295-9. PubMed Abstract | Publisher Full Text | Free Full Text

33. $\mathrm{F}$ Haas $\mathrm{TL}$, Emmerich $\mathrm{CH}$, Gerlach B, et al:: Recruitment of the linear ubiquitin chain assembly complex stabilizes the TNF-R1 signaling complex and is required for TNF-mediated gene induction. Mol Cell. 2009; 36(5): 831-44. PubMed Abstract | Publisher Full Text | F1000 Recommendation

34. $\mathrm{F}$ Emmerich $\mathrm{CH}$, Ordureau A, Strickson $\mathrm{S}$, et al: Activation of the canonical IKK complex by K63/M1-linked hybrid ubiquitin chains. Proc Natl Acad Sci U S A. 2013; 110(38): 15247-52.

PubMed Abstract | Publisher Full Text | Free Full Text | F1000 Recommendation

35. Emmerich $\mathrm{CH}$, Bakshi S, Kelsall IR, et al:: Lys63/Met1-hybrid ubiquitin chains are commonly formed during the activation of innate immune signalling. Biochem Biophys Res Commun. 2016; 474(3): 452-61.

PubMed Abstract | Publisher Full Text | Free Full Text

36. Beg AA, Baltimore D: An essential role for NF-kappaB in preventing TNF-alphainduced cell death. Science. 1996; 274(5288): 782-4.

PubMed Abstract | Publisher Full Text

37. Gozzelino R, Sole C, Llecha N, et al:: BCL-X regulates TNF-alpha-mediated cell death independently of NF-kappaB, FLIP and IAPs. Cell Res. 2008; 18(10): 1020-36.

PubMed Abstract | Publisher Full Text

38. Tsuchiya Y, Nakabayashi O, Nakano H: FLIP the Switch: Regulation of Apoptosis and Necroptosis by cFLIP. Int J Mol Sci. 2015; 16(12): 30321-41. PubMed Abstract | Publisher Full Text | Free Full Text

39. O'Donnell MA, Legarda-Addison D, Skountzos $\mathrm{P}$, et al:: Ubiquitination of RIP1 regulates an NF-kappaB-independent cell-death switch in TNF signaling. Cur Biol. 2007; 17(5): 418-24.

PubMed Abstract | Publisher Full Text | Free Full Text

40. F Ea CK, Deng L, Xia ZP, et al:: Activation of IKK by TNFalpha requires sitespecific ubiquitination of RIP1 and polyubiquitin binding by NEMO. Mol Cell. 2006; 22(2): 245-57.

PubMed Abstract | Publisher Full Text | F1000 Recommendation

41. F Annibaldi A, Wicky John S, Vanden Berghe T, et al:: Ubiquitin-Mediated Regulation of RIPK1 Kinase Activity Independent of IKK and MK2. Mol Cell. 2018; 69(4): 566-580.e5.

PubMed Abstract | Publisher Full Text | Free Full Text | F1000 Recommendation

42. F Kovalenko A, Chable-Bessia C, Cantarella G, et al:: The tumour suppressor CYLD negatively regulates NF-kappaB signalling by deubiquitination. Nature. 2003; 424(6950): 801-5.

PubMed Abstract | Publisher Full Text | F1000 Recommendation

43. F Bertrand MJ, Milutinovic S, Dickson KM, et al.: cIAP1 and cIAP2 facilitate cancer cell survival by functioning as E3 ligases that promote RIP1 ubiquitination. Mol Cell. 2008; 30(6): 689-700

PubMed Abstract | Publisher Full Text | F1000 Recommendation

44. F Oberst A, Dillon CP, Weinlich R, et al.: Catalytic activity of the caspase-8 FLIP ${ }_{L}$ complex inhibits RIPK3-dependent necrosis. Nature. 2011; 471(7338): 363-7.

PubMed Abstract | Publisher Full Text | Free Full Text | F1000 Recommendation

45. Park $\mathrm{YC}, \mathrm{Ye} \mathrm{H}, \mathrm{Hsia} \mathrm{C}$, et al:: A novel mechanism of TRAF signaling revealed by structural and functional analyses of the TRADD-TRAF2 interaction. Cell. 2000; 101(7): 777-87.

PubMed Abstract | Publisher Full Text

46. $\mathrm{Ye} \mathrm{H}, \mathrm{Wu} \mathrm{H}$ : Thermodynamic characterization of the interaction between TRAF2 and tumor necrosis factor receptor peptides by isothermal titration calorimetry. Proc Natl Acad Sci U S A. 2000; 97(16): 8961-6.

PubMed Abstract | Publisher Full Text | Free Full Text

47. Grech AP, Gardam S, Chan T, et al.: Tumor necrosis factor receptor 2 (TNFR2) signaling is negatively regulated by a novel, carboxyl-terminal TNFRassociated factor 2 (TRAF2)-binding site. J Biol Chem. 2005; 280(36): 31572-81.

PubMed Abstract | Publisher Full Text

48. F Wertz IE, O'Rourke $\mathrm{KM}$, Zhou $\mathrm{H}$, et al:: De-ubiquitination and ubiquitin ligase domains of A20 downregulate NF-kappaB signalling. Nature. 2004 430(7000): 694-9.

PubMed Abstract | Publisher Full Text | F1000 Recommendation

49. Lu TT, Onizawa M, Hammer GE, et al: Dimerization and ubiquitin mediated recruitment of A20, a complex deubiquitinating enzyme. Immunity. 2013; 38(5): 896-905

PubMed Abstract | Publisher Full Text | Free Full Text

50. Tokunaga $F$, Nishimasu $H$, Ishitani $R$, et al:: Specific recognition of linear polyubiquitin by $\mathbf{A} 20$ zinc finger 7 is involved in NF-кB regulation. EMBO J. 2012; 31(19): 3856-70.

PubMed Abstract | Publisher Full Text | Free Full Text

51. Verhelst K, Carpentier I, Kreike M, et al.: A20 inhibits LUBAC-mediated NF-кB activation by binding linear polyubiquitin chains via its zinc finger 7 . EMBO 2012; 31(19): 3845-55.

PubMed Abstract | Publisher Full Text | Free Full Text

52. F Shembade N, Ma A, Harhaj EW: Inhibition of NF-kappaB signaling by A20 through disruption of ubiquitin enzyme complexes. Science. 2010; 327(5969): 1135-9.

PubMed Abstract | Publisher Full Text | Free Full Text | F1000 Recommendation

53. Draber P, Kupka S, Reichert M, et al.: LUBAC-Recruited CYLD and A20 Regulate Gene Activation and Cell Death by Exerting Opposing Effects on Linear Ubiquitin in Signaling Complexes. Cell Rep. 2015; 13(10): 2258-72. PubMed Abstract | Publisher Full Text | Free Full Text

54. Elliott PR, Nielsen SV, Marco-Casanova $P$, et al:: Molecular basis and regulation of OTULIN-LUBAC interaction. Mol Cell. 2014; 54(3): 335-48.

PubMed Abstract | Publisher Full Text | Free Full Text

55. Blake PW, Toro JR: Update of cylindromatosis gene (CYLD) mutations in Brooke-Spiegler syndrome: novel insights into the role of deubiquitination in cell signaling. Hum Mutat. 2009; 30(7): 1025-36.

PubMed Abstract | Publisher Full Text | Free Full Text

56. F Amin P, Florez M, Najafov A, et al.: Regulation of a distinct activated RIPK intermediate bridging complex I and complex II in TNF $\alpha$-mediated apoptosis. Proc Natl Acad Sci U S A. 2018; 115(26): E5944-E5953. PubMed Abstract | Publisher Full Text | Free Full Text | F1000 Recommendation

57. F Hitomi J, Christofferson DE, $\mathrm{Ng} \mathrm{A}$, et al:: Identification of a molecular signaling network that regulates a cellular necrotic cell death pathway. Cell. 2008; 135(7): 1311-23.

PubMed Abstract | Publisher Full Text | Free Full Text | F1000 Recommendation

58. Dondelinger $\mathrm{Y}$, Jouan-Lanhouet S, Divert T, et al:: NF-кB-Independent Role of IKK $\alpha /$ IKK $\beta$ in Preventing RIPK1 Kinase-Dependent Apoptotic and Necroptotic Cell Death during TNF Signaling. Mol Cell. 2015; 60(1): 63-76. PubMed Abstract | Publisher Full Text

59. $\quad \mathrm{F}$ Geng J, Ito $\mathrm{Y}$, Shi L, et al:: Regulation of RIPK1 activation by TAK1-mediated phosphorylation dictates apoptosis and necroptosis. Nat Commun. 2017; 8(1):

PubMed Abstract | Publisher Full Text | Free Full Text | F1000 Recommendation

60. F Meng H, Liu Z, Li X, et al:: Death-domain dimerization-mediated activation of RIPK1 controls necroptosis and RIPK1-dependent apoptosis. Proc Natl Acad Sci U S A. 2018; 115(9): E2001-E2009.

PubMed Abstract | Publisher Full Text | Free Full Text | F1000 Recommendation

61. Jarosz-Griffiths HH, Noble E, Rushworth JV, et al:: Amyloid- $\beta$ Receptors: The Good, the Bad, and the Prion Protein. J Biol Chem. 2016; 291(7): 3174-83. PubMed Abstract | Publisher Full Text | Free Full Text

62. F Lin J, Kumari S, Kim C, et al:: RIPK1 counteracts ZBP1-mediated necroptosis to inhibit inflammation. Nature. 2016; 540(7631): 124-128. PubMed Abstract | Publisher Full Text | Free Full Text | F1000 Recommendation

63. F Newton K, Wickliffe KE, Maltzman A, et al:: RIPK1 inhibits ZBP1-driven necroptosis during development. Nature. 2016; 540(7631): 129-133. PubMed Abstract | Publisher Full Text | F1000 Recommendation 
64. F Newton K, Dugger DL, Maltzman A, et al:: RIPK3 deficiency or catalytically inactive RIPK1 provides greater benefit than MLKL deficiency in mouse models of inflammation and tissue injury. Cell Death Differ. 2016; 23(9): 1565-76. PubMed Abstract | Publisher Full Text | Free Full Text | F1000 Recommendation

65. F Garcia-Carbonell R, Wong J, Kim JY, et al:: Elevated A20 promotes TNFinduced and RIPK1-dependent intestinal epithelial cell death. Proc Natl Acad Sci U S A. 2018; 115(39): E9192-E9200.

PubMed Abstract | Publisher Full Text | Free Full Text | F1000 Recommendation

66. F Onizawa M, Oshima S, Schulze-Topphoff $U$, et al.: The ubiquitin-modifying enzyme A20 restricts ubiquitination of the kinase RIPK3 and protects cells from necroptosis. Nat Immunol. 2015; 16(6): 618-27.

PubMed Abstract | Publisher Full Text | Free Full Text | F1000 Recommendation

67. F Anderton H, Rickard JA, Varigos GA, et al:: Inhibitor of Apoptosis Proteins (IAPs) Limit RIPK1-Mediated Skin Inflammation. J Invest Dermatol. 2017; 137(11): 2371-2379.

PubMed Abstract | Publisher Full Text | F1000 Recommendation

68. Lawlor KE, Khan N, Mildenhall A, et al:: RIPK3 promotes cell death and NLRP3 inflammasome activation in the absence of MLKL. Nat Commun. 2015; 6: 6282 . PubMed Abstract | Publisher Full Text | Free Full Text

69. F Conos SA, Chen KW, De Nardo D, et al:: Active MLKL triggers the NLRP3 inflammasome in a cell-intrinsic manner. Proc Natl Acad Sci U S A. 2017; 114(6): E961-E969.

PubMed Abstract | Publisher Full Text | Free Full Text | F1000 Recommendation

70. F Chen KW, Lawlor KE, von Pein JB, et al:: Cutting Edge: Blockade of Inhibitor of Apoptosis Proteins Sensitizes Neutrophils to TNF- but Not Lipopolysaccharide-Mediated Cell Death and IL-1ß Secretion. J Immunol. 2018; 200(10): 3341-3346.

PubMed Abstract | Publisher Full Text | F1000 Recommendation

71. Zhong H, Bussel J, Yazdanbakhsh K: In vitro TNF blockade enhances ex vivo expansion of regulatory $\mathrm{T}$ cells in patients with immune thrombocytopenia. Br J Haematol. 2015; 168(2): 274-83.

PubMed Abstract | Publisher Full Text | Free Full Text

72. F Shaikh F, He J, Bhadra P, et al:: TNF Receptor Type II as an Emerging Drug Target for the Treatment of Cancer, Autoimmune Diseases, and Graft-VersusHost Disease: Current Perspectives and In Silico Search for Small Molecule Binders. Front Immunol. 2018; 9: 1382.

PubMed Abstract | Publisher Full Text | Free Full Text | F1000 Recommendation

73. Zou H, Li R, Hu H, et al:: Modulation of Regulatory T Cell Activity by TNF Receptor Type II-Targeting Pharmacological Agents. Front Immunol. 2018; 9: 594. PubMed Abstract | Publisher Full Text | Free Full Text

74. Boks MA, Kager-Groenland JR, Mousset CM, et al:: Inhibition of TNF receptor signaling by anti-TNF $\alpha$ biologicals primes naïve CD4 ${ }^{+} \mathrm{T}$ cells towards IL-10 $\mathrm{T}$ cells with a regulatory phenotype and function. Clin Immunol. 2014; 151(2) $136-45$.

PubMed Abstract | Publisher Full Text

75. Zhu M, Lei L, Zhu Z, et al.: Excess TNF- $\alpha$ in the blood activates monocytes with the potential to directly form cholesteryl ester-laden cells. Acta Biochim Biophys Sin (Shanghai). 2015; 47(11): 899-907.

PubMed Abstract | Publisher Full Tex

76. Paladino N, Mul Fedele ML, Duhart JM, et al:: Modulation of mammalian circadian rhythms by tumor necrosis factor- $\alpha$. Chronobiol Int. 2014; 31(5): 668-79.

PubMed Abstract | Publisher Full Text

77. F Abreu M, Basti A, Genov N, et al:: The reciprocal interplay between TNFo and the circadian clock impacts on cell proliferation and migration in Hodgkin lymphoma cells. Sci Rep. 2018; 8(1): 11474

PubMed Abstract | Publisher Full Text | Free Full Text | F1000 Recommendation

78. F Yoshida K, Nakai A, Kaneshiro K, et al.: TNF- $\alpha$ induces expression of the circadian clock gene Bmal1 via dual calcium-dependent pathways in rheumatoid synovial cells. Biochem Biophys Res Commun. 2018; 495(2): $1675-1680$

PubMed Abstract | Publisher Full Text | F1000 Recommendation

79. Matsuzawa $Y$, Oshima S, Takahara M, et al: TNFAIP3 promotes survival of CD4 T cells by restricting MTOR and promoting autophagy. Autophagy. 2015; 11(7): 1052-62.

PubMed Abstract | Publisher Full Text | Free Full Text

80. F Fischer JC, Otten V, Kober M, et al.: A20 Restrains Thymic Regulatory T Cell Development. J Immunol. 2017; 199(7): 2356-2365.

PubMed Abstract | Publisher Full Text | Free Full Text | F1000 Recommendation

81. F Just $\mathrm{S}$, Nishanth G, Buchbinder JH, et al.: A20 Curtails Primary but Augments Secondary CD8+T Cell Responses in Intracellular Bacterial Infection. Sci Rep. 2016; 6: 39796

PubMed Abstract | Publisher Full Text | Free Full Text | F1000 Recommendation

82. F Park $\mathrm{Y}$, Jin HS, Lopez J, et al.: SHARPIN controls regulatory $\mathrm{T}$ cells by negatively modulating the $\mathrm{T}$ cell antigen receptor complex. Nat Immunol. 2016; 17(3): 286-96.

PubMed Abstract | Publisher Full Text | Free Full Text | F1000 Recommendation

83. Redecke V, Chaturvedi V, Kuriakose J, et al:: SHARPIN controls the development of regulatory T cells. Immunology. 2016; 148(2): 216-26.

PubMed Abstract | Publisher Full Text | Free Full Text
84. Elton L, Carpentier I, Staal J, et al:: MALT1 cleaves the E3 ubiquitin ligase HOIL-1 in activated T cells, generating a dominant negative inhibitor of LUBAC-induced NF-кB signaling. FEBS J. 2016; 283(3): 403-12

PubMed Abstract | Publisher Full Text

85. F Klein T, Fung SY, Renner F, et al:: The paracaspase MALT1 cleaves HOIL1 reducing linear ubiquitination by LUBAC to dampen lymphocyte NF- $\mathrm{KB}$ signalling. Nat Commun. 2015; 6: 8777 .

PublMed Abstract | Publisher Full Text | Free Full Text | F1000 Recommendation

86. Douanne T, Gavard J, Bidère N: The paracaspase MALT1 cleaves the LUBAC subunit HOIL1 during antigen receptor signaling. J Cell Sci. 2016; 129(9): $1775-80$.

PubMed Abstract | Publisher Full Text

87. Hailfinger S, Schmitt A, Schulze-Osthoff $K$ : The paracaspase MALT1 dampens NF-кB signalling by cleaving the LUBAC subunit HOIL-1. FEBS J. 2016; 283(3): 400-2.

PubMed Abstract | Publisher Full Text

88. Coornaert $\mathrm{B}$, Baens $\mathrm{M}$, Heyninck $\mathrm{K}$, et al.: $\mathrm{T}$ cell antigen receptor stimulation induces MALT1 paracaspase-mediated cleavage of the NF-kappaB inhibito A20. Nat Immunol. 2008; 9(3): 263-71.

PubMed Abstract | Publisher Full Text

89. F Hailfinger S, Nogai $\mathrm{H}$, Pelzer $\mathrm{C}$, et al.: Malt1-dependent RelB cleavage promotes canonical NF-kappaB activation in lymphocytes and lymphoma cell lines. Proc Natl Acad Sci U S A. 2011; 108(35): 14596-601. PubMed Abstract | Publisher Full Text | Free Full Text | F1000 Recommendation

90. Staal J, Driege $\mathrm{Y}$, Bekaert T, et al:: T-cell receptor-induced JNK activation requires proteolytic inactivation of CYLD by MALT1. EMBO J. 2011; 30(9): 1742-52.

PubMed Abstract | Publisher Full Text | Free Full Text

91. Baens M, Bonsignore L, Somers R, et al:: MALT1 auto-proteolysis is essential for NF-кB-dependent gene transcription in activated lymphocytes. PLoS One. 2014; 9(8): e103774.

PubMed Abstract | Publisher Full Text | Free Full Text

92. Francisco NM, Hsu NJ, Keeton R, et al.: TNF-dependent regulation and activation of innate immune cells are essential for host protection against cerebral tuberculosis. J Neuroinflammation. 2015; 12: 125. PubMed Abstract | Publisher Full Text | Free Full Text

93. F Hartley G, Regan D, Guth A, et al:: Regulation of PD-L1 expression on murine tumor-associated monocytes and macrophages by locally produced TNF-a. Cancer Immunol Immunother. 2017; 66(4): 523-35.

PubMed Abstract | Publisher Full Text | F1000 Recommendation

94. F Wang X, Yang L, Huang F, et al:: Inflammatory cytokines IL-17 and TNFup-regulate PD-L1 expression in human prostate and colon cancer cells. Immunol Lett. 2017: 184: 7-14.

PubMed Abstract | Publisher Full Text | Free Full Text | F1000 Recommendation

95. Pekala $\mathrm{P}$, Kawakami $\mathrm{M}$, Vine $\mathrm{W}$, et al:: Studies of insulin resistance in adipocytes induced by macrophage mediator. J Exp Med. 1983; 157(4): 1360-5. PubMed Abstract | Publisher Full Text | Free Full Text

96. Mahoney JR Jr, Beutler BA, Le Trang N, et al.: Lipopolysaccharide-treated RAW 264.7 cells produce a mediator that inhibits lipoprotein lipase in 3T3-L1 cells. J Immunol. 1985; 134(3): 1673-5.

PubMed Abstract

97. Kern PA, Saghizadeh M, Ong JM, et al:: The expression of tumor necrosis factor in human adipose tissue. Regulation by obesity, weight loss, and relationship to lipoprotein lipase. J Clin Invest. 1995; 95(5): 2111-9. PubMed Abstract | Publisher Full Text | Free Full Text

98. Hotamisligil GS, Arner P, Caro JF, et al.: Increased adipose tissue expression of tumor necrosis factor-alpha in human obesity and insulin resistance. $J$ Clin Invest. 1995; 95(5): 2409-15.

PubMed Abstract | Publisher Full Text | Free Full Text

99. Saghizadeh M, Ong JM, Garvey WT, et al:: The expression of TNF alpha by human muscle. Relationship to insulin resistance. J Clin Invest. 1996; 97(4) 1111-6.

PubMed Abstract | Publisher Full Text | Free Full Text

100. Hotamisligil GS, Shargill NS, Spiegelman BM: Adipose expression of tumor necrosis factor-alpha: direct role in obesity-linked insulin resistance. Science. 1993; 259(5091): 87-91.

PubMed Abstract | Publisher Full Text

101. Borst SE, Bagby GJ: Neutralization of tumor necrosis factor reverses age-induced impairment of insulin responsiveness in skeletal muscle of Sprague-Dawley rats. Metabolism. 2002; 51(8): 1061-4. PubMed Abstract | Publisher Full Text

102. Ling PR, Bistrian BR, Mendez B, et al:: Effects of systemic infusions of endotoxin, tumor necrosis factor, and interleukin-1 on glucose metabolism in the rat: relationship to endogenous glucose production and peripheral tissue glucose uptake. Metabolism. 1994; 43(3): 279-84. PubMed Abstract | Publisher Full Text

103. Miles $\mathrm{PD}$, Romeo OM, Higo K, et al.: TNF-alpha-induced insulin resistance in vivo and its prevention by troglitazone. Diabetes. 1997; 46(11): 1678-83. PubMed Abstract | Publisher Full Text

104. F Millet $P$, Vachharajani V, McPhail $L$, et al.: GAPDH Binding to TNF- $\alpha$ mRNA Contributes to Posttranscriptional Repression in Monocytes: A Novel Mechanism of Communication between Inflammation and Metabolism. 
J Immunol. 2016; 196(6): 2541-51.

PubMed Abstract | Publisher Full Text | Free Full Text | F1000 Recommendation

105. $\mathrm{F}$ Nakano $\mathrm{T}$, Goto $\mathrm{S}$, Takaoka $\mathrm{Y}$, et al:: A novel moonlight function of glyceraldehyde-3-phosphate dehydrogenase (GAPDH) for immunomodulation. Biofactors. 2018; 44(6): 597-608.

PubMed Abstract | Publisher Full Text | F1000 Recommendation

106. F Mills EL, Ryan DG, Prag HA, et al:: Itaconate is an anti-inflammatory metabolite that activates Nrf2 via alkylation of KEAP1. Nature. 2018; 556(7699): 113-7.

PubMed Abstract | Publisher Full Text | Free Full Text | F1000 Recommendation

107. F Littlewood-Evans A, Sarret S, Apfel V, et al.: GPR91 senses extracellular succinate released from inflammatory macrophages and exacerbates rheumatoid arthritis. J Exp Med. 2016; 213(9): 1655-62.

PubMed Abstract | Publisher Full Text | Free Full Text | F1000 Recommendation

108. Jamal Uddin M, Joe Y, Kim SK, et al:: IRG1 induced by heme oxygenase-1/ carbon monoxide inhibits LPS-mediated sepsis and pro-inflammatory cytokine production. Cell Mol Immunol. 2015; 13(2): 170-9. PubMed Abstract | Publisher Full Text | Free Full Text

109. Bae S, Kim H, Lee N, et al.: $\alpha$-Enolase expressed on the surfaces of monocytes and macrophages induces robust synovial inflammation in rheumatoid arthritis. J Immunol. 2012; 189(1): 365-72. PubMed Abstract | Publisher Full Text

110. De Rosa V, Galgani M, Porcellini A, et al.: Glycolysis controls the induction of human regulatory $\mathrm{T}$ cells by modulating the expression of FOXP3 exon 2 splicing variants. Nat Immunol. 2015; 16(11): 1174-84. PubMed Abstract | Publisher Full Text | Free Full Text

111. F Davies LC, Rice CM, Palmieri EM, et al:: Peritoneal tissue-resident macrophages are metabolically poised to engage microbes using tissue-niche fuels. Nat Commun. 2017; 8(1): 2074.

PubMed Abstract | Publisher Full Text | Free Full Text | F1000 Recommendation

112. Infantino $\mathrm{V}$, lacobazzi $\mathrm{V}$, Menga $\mathrm{A}$, et al:: $\mathbf{A}$ key role of the mitochondrial citrate carrier (SLC25A1) in TNF $\alpha$ - and IFN $\gamma$-triggered inflammation. Biochim Biophys Acta. 2014; 1839(11): 1217-25.

PubMed Abstract | Publisher Full Text | Free Full Text

113. Moon JS, Lee S, Park MA, et al:: UCP2-induced fatty acid synthase promotes NLRP3 inflammasome activation during sepsis. J Clin Invest. 2015; 125(2): $665-80$.

PubMed Abstract | Publisher Full Text | Free Full Text

114. Wei $X$, Song $\mathrm{H}$, Yin L, et al.: Fatty acid synthesis configures the plasma membrane for inflammation in diabetes. Nature. 2016; 539(7628): 294-8. PubMed Abstract | Publisher Full Text | Free Full Text

115. McDermott MF, Aksentijevich I, Galon J, et al:: Germline mutations in the extracellular domains of the $55 \mathrm{kDa}$ TNF receptor, TNFR1, define a family of dominantly inherited autoinflammatory syndromes. Cell. 1999; 97(1): 133-44. PubMed Abstract | Publisher Full Text

116. Quillinan N, Mannion G, Mohammad A, et al:: Failure of sustained response to etanercept and refractoriness to anakinra in patients with T50M TNF-receptorassociated periodic syndrome. Ann Rheum Dis. 2011; 70(9): 1692-3. PubMed Abstract | Publisher Full Text

117. Bulua AC, Mogul DB, Aksentijevich I, et al.: Efficacy of etanercept in the tumor necrosis factor receptor-associated periodic syndrome: a prospective, open-label, dose-escalation study. Arthritis Rheum. 2012; 64(3): 908-13. PubMed Abstract | Publisher Full Text | Free Full Text

118. F Torene R, Nirmala N, Obici L, et al:: Canakinumab reverses overexpression of inflammatory response genes in tumour necrosis factor receptor-associated periodic syndrome. Ann Rheum Dis. 2017; 76(1): 303-9.

PubMed Abstract | Publisher Full Text | Free Full Text | F1000 Recommendation

119. Gattorno M, Obici L, Cattalini M, et al.: Canakinumab treatment for patients with active recurrent or chronic TNF receptor-associated periodic syndrome (TRAPS): an open-label, phase II study. Ann Rheum Dis. 2016; 76(1): 173-8. PubMed Abstract | Publisher Full Text | Free Full Text

120. La Torre F, Muratore M, Vitale A, et al:: Canakinumab efficacy and long-term tocilizumab administration in tumor necrosis factor receptor-associated periodic syndrome (TRAPS). Rheumatol Int. 2015; 35(11): 1943-7. PubMed Abstract | Publisher Full Text

121. Akasbi N, Soyfoo MS: Successful treatment of tumor necrosis factor receptorassociated periodic syndrome (TRAPS) with tocilizumab: A case report. Eur Rheumatol. 2015; 2(1): 35-6. PubMed Abstract | Publisher Full Text | Free Full Text

122. Vaitla PM, Radford PM, Tighe PJ, et al:: Role of interleukin-6 in a patient with tumor necrosis factor receptor-associated periodic syndrome: Assessment of outcomes following treatment with the anti-interleukin- 6 receptor monoclonal antibody tocilizumab. Arthritis Rheum. 2011; 63(4): 1151-5. PubMed Abstract | Publisher Full Text

123. Hosoya T, Mizoguchi F, Hasegawa H, et al:: A Case Presenting with the Clinical Characteristics of Tumor Necrosis Factor (TNF) Receptor-associated Periodic Syndrome (TRAPS) without TNFRSF1A Mutations Successfully Treated with
Tocilizumab. Intern Med. 2015; 54(16): 2069-72.

PubMed Abstract | Publisher Full Text

124. Aksentijevich I, McDermott MF: Lessons from characterization and treatment of the autoinflammatory syndromes. Curr Opin Rheumatol. 2017; 29(2): 187-94. PubMed Abstract | Publisher Full Text | Free Full Text

125. Cohen $P$ : Immune diseases caused by mutations in kinases and components of the ubiquitin system. Nat Immunol. 2014; 15(6): 521-9. PubMed Abstract | Publisher Full Text | Free Full Text

126. Zhou Q, Yu X, Demirkaya E, et al.: Biallelic hypomorphic mutations in a linear deubiquitinase define otulipenia, an early-onset autoinflammatory disease. Proc Natl Acad Sci U S A. 2016; 113(36): 10127-32. PubMed Abstract | Publisher Full Text | Free Full Text

127. F Damgaard RB, Walker JA, Marco-Casanova $P$, et al.: The Deubiquitinase OTULIN Is an Essential Negative Regulator of Inflammation and Autoimmunity. Cell. 2016; 166(5): 1215-1230.e20.

PubMed Abstract | Publisher Full Text | Free Full Text | F1000 Recommendation

128. $\mathrm{F}$ Zhou $\mathrm{Q}$, Wang $\mathrm{H}$, Schwartz DM, et al.: Loss-of-function mutations in TNFAIP3 leading to A20 haploinsufficiency cause an early-onset autoinflammatory disease. Nat Genet. 2016; 48(1): 67-73. PubMed Abstract | Publisher Full Text | Free Full Text | F1000 Recommendation

129. Kadowaki T, Ohnishi H, Kawamoto N, et al.: Haploinsufficiency of A20 causes autoinflammatory and autoimmune disorders. J Allergy Clin Immunol. 2018; 141(4): 1485-1488.e11.

PubMed Abstract | Publisher Full Text

130. McInnes IB, Schett G: The pathogenesis of rheumatoid arthritis. N Engl J Med. 2011; 365(23): 2205-19. PubMed Abstract | Publisher Full Text

131. Viatte S, Plant D, Bowes J, et al:: Genetic markers of rheumatoid arthritis susceptibility in anti-citrullinated peptide antibody negative patients. Ann Rheum Dis. 2012; 71(12): 1984-90. PubMed Abstract | Publisher Full Text | Free Full Text

132. F Aki A, Nagasaki M, Malynn BA, et al:: Hypomorphic A20 expression confers susceptibility to psoriasis. PLOS One. 2017; 12(6): e0180481. PubMed Abstract | Publisher Full Text | Free Full Text | F1000 Recommendation

133. Adrianto I, Wen F, Templeton A, et al.: Association of a functional variant downstream of TNFAIP3 with systemic lupus erythematosus. Nat Genet. 2011; 43(3): 253-8.

PubMed Abstract | Publisher Full Text | Free Full Text

134. $\mathrm{F}$ Zaidi $\mathrm{D}$, Huynh $\mathrm{H}$, Carroll $\mathrm{M}$, et al:: Tumor necrosis factor $\alpha$-induced protein 3 (A20) is dysregulated in pediatric Crohn disease. CEG. 2018; 11: 217-231.

PubMed Abstract | Publisher Full Text | Free Full Text | F1000 Recommendation

135. $\mathrm{F}$ Zheng $\mathrm{C}$, Huang $\mathrm{Y}, \mathrm{Ye} Z$, et al.: Infantile Onset Intractable Inflammatory Bowel Disease Due to Novel Heterozygous Mutations in TNFAIP3 (A20). Inflamm Bowel Dis. 2018; 24(12): 2613-2620.

PubMed Abstract | Publisher Full Text | F1000 Recommendation

136. F Aeschlimann FA, Batu ED, Canna SW, et al:: A20 haploinsufficiency (HA20): clinical phenotypes and disease course of patients with a newly recognised NF-kB-mediated autoinflammatory disease. Ann Rheum Dis. 2018; 77(5): 728-735. PubMed Abstract | Publisher Full Text | F1000 Recommendation

137. F Vande Walle $L$, van Opdenbosch $\mathrm{N}$, Jacques $\mathrm{P}$, et al:: Negative regulation of the NLRP3 inflammasome by A20 protects against arthritis. Nature. 2014; 512(7512): 69-73.

PubMed Abstract | Publisher Full Text | Free Full Text | F1000 Recommendation

138. F Taraborrelli L, Peltzer N, Montinaro A, et al:: LUBAC prevents lethal dermatitis by inhibiting cell death induced by TNF, TRAIL and CD95L. Nat Commun. 2018; 9(1): 3910.

PubMed Abstract | Publisher Full Text | Free Full Text | F1000 Recommendation

139. Boisson B, Laplantine $\mathrm{E}$, Dobbs $\mathrm{K}$, et al:: Human HOIP and LUBAC deficiency underlies autoinflammation, immunodeficiency, amylopectinosis, and lymphangiectasia. J Exp Med. 2015; 212(6): 939-51. PubMed Abstract | Publisher Full Text | Free Full Text

140. F Boisson B, Laplantine E, Prando C, et al.: Immunodeficiency, autoinflammation and amylopectinosis in humans with inherited HOIL-1 and LUBAC deficiency. Nat Immunol. 2012; 13(12): 1178-86. PubMed Abstract | Publisher Full Text | Free Full Text | F1000 Recommendation

141. F Krenn M, Salzer E, Simonitsch-Klupp I, et al.: Mutations outside the $\mathrm{N}$-terminal part of RBCK1 may cause polyglucosan body myopathy with immunological dysfunction: expanding the genotype-phenotype spectrum. J Neurol. 2018; 265(2): 394-401.

PubMed Abstract | Publisher Full Text | Free Full Text | F1000 Recommendation

142. Sennikov SV, Alshevskaya AA, Shkaruba NS, et al.: Expression of TNF $\alpha$ membrane-bound receptors in the peripheral blood mononuclear cells (PMBC) in rheumatoid arthritis patients. Cytokine. 2015; 73(2): 288-94.

PubMed Abstract | Publisher Full Text 


\section{Open Peer Review}

\section{Current Peer Review Status:}

\section{Editorial Note on the Review Process}

Faculty Reviews are review articles written by the prestigious Members of Faculty Opinions. The articles are commissioned and peer reviewed before publication to ensure that the final, published version is comprehensive and accessible. The reviewers who approved the final version are listed with their names and affiliations.

\section{The reviewers who approved this article are:}

\section{Version 1}

\section{Lisa Sedger}

Faculty of Science, The University of Technology , Sydney, Australia

Competing Interests: No competing interests were disclosed.

\section{Rudi Beyaert}

Department of Biomedical Molecular Biology, Ghent University, Technologiepark 927, Zwijnaarde, Ghent, 9052, Belgium

Competing Interests: No competing interests were disclosed.

The benefits of publishing with F1000Research:

- Your article is published within days, with no editorial bias

- You can publish traditional articles, null/negative results, case reports, data notes and more

- The peer review process is transparent and collaborative

- Your article is indexed in PubMed after passing peer review

- Dedicated customer support at every stage

For pre-submission enquiries, contact research@f1000.com 